\title{
Rock Shelters, Caves, and Archaeobotany in Island Southeast Asia
}

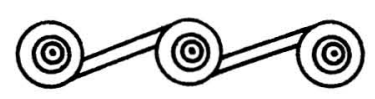

VICTOR PAZ

CAVES AND ROCK SHELTERS are the dominant site types in Island Southeast Asia. Ever since the pioneering times of archaeological practice in the region, archaeologists have commonly assumed that these were the best sites to start with in the search for very old archaeological deposits. There is also the issue of accessibility: caves and rock shelters in the region usually offer a deeper chronology for less matrix depth than open sites. At most sites of this type, alluvial or colluvial deposition are not major factors in the creation of their matrices.

Taphonomic processes also have a more destructive effect on the archaeology found at open sites, making it harder for the archaeologist (and especially the archaeobotanist) to study the remains. Good cave sites in particular have the advantage of being relatively dry, even in the tropics, creating excellent conditions for preservation. This is seen clearly in the preservation of organic materials. In the Niah cave complex in Sarawak, for example, wooden planks and coffins survive exposed on the surface or buried underneath layers of guano in the West Mouth of the Great Cave and in Kain Hitam, the Painted Cave (Barker et al. 2001; Harrisson 1958). Another example is the mummified human remains and coffins in the caves located in Kabayan in the Cordillera mountains of Luzon (Salcedo 1998).

Cave sites can be compared with other cave sites fairly easily. The extent of what constitutes an archaeological site can be defined clearly as the area within the cave or cave platform. The borders of open sites, on the other hand, are usually defined arbitrarily in Island Southeast Asia. The fact that caves and rock shelters have offered the more attractive options for many archaeologists working in the region does not imply that such sites do not have their own set of complications (see Bell and Walker 1992:33-34; Spriggs 1989). With open sites, everyone knows the difficulties almost immediately. With caves and rock shelters, there has sometimes been a degree of naïveté when dealing with the intricacies of site formation processes (Barker et al. 2000; Spriggs 1989; and see this volume: Gilbertson et al.). Nevertheless, caves and rock shelters may be treated as effective units 
of analysis for archaeological studies, especially when the emphasis is on peoplelandscape or people-plant relationships in the past.

\section{THE DEVELOPMENT OF ARCHAEOBOTANY IN THE REGION}

Archaeobotany is the analysis of plant remains from archaeological sites and contexts. An archaeobotanist treats plant remains in their various forms of preservation mainly as artifacts. Only when the sampling is off site and the concern is for paleoenvironmental reconstructions are the plant remains treated as ecofacts. Some examples of the latter approach in Island Southeast Asia are the various offsite palynological studies undertaken by Maloney $(1985,1990)$ in the island of Sumatra and van der Kaars and Dam (1997) in Java, and more general coverage of the Indonesian archipelago by Dam et al. (2001), research that indirectly addressed questions of human impact on the landscape. Archaeobotanists collect and study plant macro remains such as charred seeds and wood, micro remains such as phytoliths and starches, and molecular remains such as ancient DNA and lipids for the purpose of understanding past human behavior and history, as well as contributing to the construction of a palaeohistorical account of the area.

While archaeobotanical studies can be carried out on all types of sites, the regional research tradition alluded to above, of studying caves and rock shelters, has created mutually beneficial conditions for the study of cave/rock shelter occupations and their archaeobotanical remains. It is no accident that the first site in Southeast Asia where an archaeobotanical data set had a worldwide impact was Spirit Cave in northern Thailand (Gorman 1971, 1977; Higham and Thosarat 1998:31; Yen 1977). The Spirit Cave plant remains were intentionally collected to address questions of early human subsistence within the context of testing the intriguing hypothesis of Carl Sauer concerning the existence of centers of domestication in Southeast Asia (Sauer 1969).

While the historical application of archaeobotanical methods has its roots in nineteenth-century archaeology (the analysis of the plant remains from the lake villages of the European alpine region), the practice of the method is far from developed in Island Southeast Asia. In general, archaeobotany here has not been well integrated within archaeological field research. In 1979 Ian Glover aptly pointed out that the fragmentary plant-remains data from past excavations in Southeast Asia had up to that time consisted almost entirely of chance finds made during archaeological research that was unrelated to questions of agriculture or plant exploitation (Glover 1979). When archaeobotanical techniques were applied, they were invariably pursued unsystematically. This can be clearly seen in the silence of state-of-the-discipline articles on the role of archaeobotany (Coutts and Wesson 1980; Dizon 1994; Evangelista 1969; Fox 1959; Jocano 1975; Mijares 1998; Ronquillo 1985; Soejono 1984, 1991). Even directed research-for example, that in the Philippines in the 1980s and 1990s - led by teams from regions of the world with well-developed archaeological methodologies, failed to apply the same enthusiasm to the recovery of archaeobotanical data that they showed to the recovery of animal remains, pottery, or stone tools (Coutts 1983; Junker 1999; Shirakihara 1983), even though on at least one occasion the stated research objective was to gain understanding of "how and when agriculture was introduced and to identify interfaces between hunter-gatherers and agriculturists" 
(Coutts 1983:9). Exceptions may be seen in the case of botanical remains embedded in pots, research coming from pottery analysis, such as the identification of embedded rice grains from northern Luzon and Panay island (Bacus 1997; Snow et al. 1986) and in more than 35 sites in Sarawak (Doherty et al. 2000).

In more recent times, archaeobotanical analysis in the region has advanced substantially in terms of the quantity of sites as well as quality of analysis. For example, methods for analyzing various types of plant remains have been fine-tuned, with the more established techniques of palynology (Penny 1999; White et al. 2003) and the analysis of plant macro remains being augmented by improved methods for identifying charred parenchyma or plant tissues (Hather 2000; Paz 2001a), starch grain determination (this volume: Barton), and phytolith analysis (Bodner 1986; Bowdery 1999). Methodologies are also being developed for analyzing charred wood and plant residues ( $\mathrm{Paz} 2001 a$; Thompson 1994).

\section{THE ARCHAEOBOTANICAL EVIDENCE}

Throughout Island Southeast Asia, there are only 29 sites that have reported results of archaeobotanical samples collected with the use of water-flotation techniques and sieving or screening of sediments (Table 1; Fig. 1). Most of the archaeobotanical materials from these sites have been investigated only during the last four years ( $\mathrm{Paz} 2001 a)$. Of the 29 sites, 15 are caves or rock shelters.

There are many ways of studying an archaeological deposit in caves. However, a good analysis of the archaeobotanical component of the cave deposit is essential if the research aim is to examine past human interaction with the surrounding landscape, or past peoples' subsistence strategies. Such data can also be crucial for addressing questions that go beyond subsistence, for example those pertaining to ritual, gender, or agency (Hastorf 1991, 1993).

Caves and rock shelters provide the best evidence for the exploitation of plant resources. These sites are not suitable for cultivating plants. As a result it is improbable that plant remains from known exploited species recovered from cave deposits were deposited in the cave without human agency. The discovery of charred plant macro remains of cultivars within cave sites makes for a secure interpretation that humans exploited these plants. The recovery, for example, of remains of woody plants, rice, sedges, and bamboo allows a nonproblematic interpretation of them as the remains of food, fuel, construction, or insulation material used by humans in caves (Glover 1986).

The vegetative organs of many plants can also be used for food or medicine, notably the tubers of plants belonging to the families Dioscoraceae (yam) and Araceae (taro). Evidence so far shows high levels of determination confidence for the exploitation of tubers of these two families from the cave sites of Madai in Sabah, Niah in Sarawak, and Leang Burung 1 in Sulawesi. At Niah, while the binomial determination was not very confident (cf. Dioscorea hispida, wild yam), the determination that the remains of the vegetative organ came from the family Dioscoraceae was high. The different specimens in the reference collection of $D$. hispida were the closest to the archaeological sample, but the archaeological sample did not have enough diagnostic features to allow strong determination at the species level (Paz 2001a: appendix; Paz 2001b:76). The Niah wild yam remains are associated with the Pleistocene and Holocene deposits in the cave, and 


\begin{tabular}{|c|c|c|c|c|c|c|}
\hline SITE & SITE TYPE & LOCATION & EXCAVATOR & ANALYZED BY & ANALYSIS & $\begin{array}{l}\text { SIGNIFICANT BEST CONFIDENCE } \\
\text { DETERMINATIONS }\end{array}$ \\
\hline Rakcuaydi & open & Batan, Batanes & Paz et al. & $\mathrm{Paz}$ & macro & prob. Colocasia tuber \\
\hline Holiday camp & open & Batan, Batanes & Paz et al. & $\mathrm{Paz}$ & macro phytoliths & Poaceae phytoliths \\
\hline Dios Dipun & rockshelter & Batan, Batanes & $\begin{array}{l}\text { Anderson Dizonm } \\
\text { et al. }\end{array}$ & $\begin{array}{r}\text { Sweet-Kelly } \\
\text { Stevenson }\end{array}$ & phytoliths & none \\
\hline Mavuyoc Aschip & open & Batan, Batanes & Bellwood et al. & Sweet-Kelly & macro phytoliths & on going \\
\hline Sunget & open & Batan, Batanes & Bellwood et al. & Sweet-Kelly Paz & macro phytoliths & on going \\
\hline Kasupitan & open & Itbayat, Batanes & Mijares & $\mathrm{Paz}$ & macro & Fabaceae seed \\
\hline Capina & open & Cagayan, Luzon & Tsang & $\mathrm{Paz}$ & macro & prob. wild yam \\
\hline Supnet & open & Cagayan, Luzon & Tsang & $\mathrm{Paz}$ & macro & prob. Dioscoraceae \\
\hline Mabangog & cave & Cagayan, Luzon & Ogawa & $\mathrm{Paz}$ & macro & Phyllanthus urinaria \\
\hline Bekes & open & Cordillera, Luzon & Bodner & Yen & macro phytoliths & Vigna sp., Amaranthus sp. \\
\hline Lubuk & open & Cordillera, Luzon & Bodner & Yen & macro phytoliths & Vigna sp., Pisum sp. \\
\hline Porac & open & Cordillera, Luzon & $\mathrm{Paz}$ & Paz \& Carlos & macro & Oryza sativa \\
\hline Angono & rockshelter & Rizal, Luzon & Bautista & $\mathrm{Paz}$ & macro & none \\
\hline Ille & rockshelter & Palawan & Solheim & Paz Sweet-Kelly & macro & on going \\
\hline Yap & open & Panay, Visayas & Bacus & $\mathrm{Paz}$ & macro & Ageratum conyzoides, Celtis sp. \\
\hline Unto & open & Panay, Visayas & Bacus & $\mathrm{Paz}$ & macro & $\begin{array}{l}\text { Oxalis corniculata, Cleome } \\
\text { viscosa }\end{array}$ \\
\hline Osmena Park & open & Panay, Visayas & Junker & Gunn & macro & Setaria sp. \\
\hline Santiago Church & open & Panay, Visayas & Junker & Gunn & macro & Cleome sp. \\
\hline Madai-1 & cave & Sabah & Bellwood & $\mathrm{Paz}$ & macro & $\begin{array}{l}\text { Dioscorea alata, D. hispida, } \\
\text { Dracontomelon dao }\end{array}$ \\
\hline Gua Sireh & cave & Sarawak & Bellwood Datan & Thompson & macro phytoliths & Oryza sativa \\
\hline Niah & cave & Sarawak & Barker et al. & $\begin{array}{l}\text { Paz, Kealhoffer, } \\
\text { Barton }\end{array}$ & $\begin{array}{l}\text { macro phytoliths } \\
\text { starch }\end{array}$ & $\begin{array}{l}\text { cf. Dioscorea hispida, Fabaceae } \\
\text { (still on going) }\end{array}$ \\
\hline Ulu Leang & cave & Sulawesi & Glover & Yen, Paz & macro & Oryza sativa, Canarium sp. \\
\hline Leang Burung & cave & Sulawesi & $\begin{array}{l}\text { Mulvaney } \\
\text { Soejono }\end{array}$ & $\mathrm{Paz}$ & macro & Colocasia esculenta, Ipomoea sp. \\
\hline Batu Ejaya 2 & cave & Sulawesi & $\begin{array}{l}\text { Mulvaney } \\
\text { Soejono }\end{array}$ & McConnell & macro & $\begin{array}{l}\text { Aleurites moluccana, Elaeocarpus } \\
\text { gigantifolius }\end{array}$ \\
\hline Pacung & open & Northern Bali & Ardika & Bowdery & phytoliths & Oryza sativa \\
\hline Lie Siri & cave & Eastern Timor & Glover & Yen & macro & Cocos sp., Zea sp. Celtis sp. \\
\hline Bui Ceri Uato & cave & Eastern Timor & Glover & Yen & macro & Areca sp. \\
\hline Uai Babo 1 & cave & Eastern Timor & Glover & Yen & macro & Cocos sp., Zea sp. Celtis sp. \\
\hline Uai Babo 2 & cave & Eastern Timor & Glover & Yen & macro & Aleurites sp., Celtis sp., Coix sp. \\
\hline
\end{tabular}

${ }^{\text {a }}$ The listed determined remains are the best examples per site. 


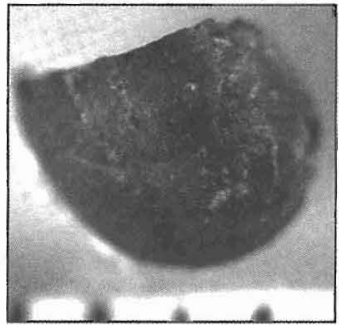

Fabaceae (legume family) Leang Burung -1

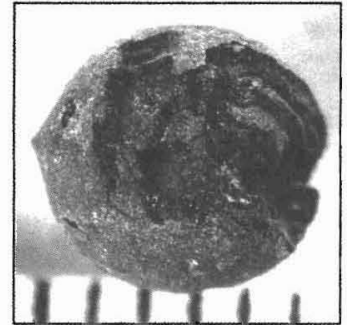

prob. I'igna sp. (pulse) Ieang Burung - 1

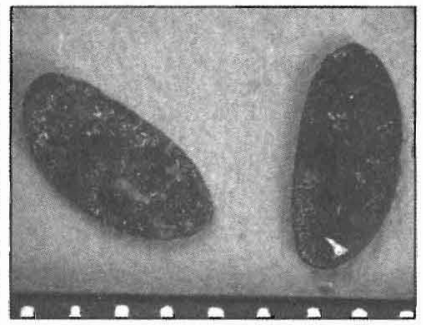

prob. Cucurbitaceae (Melon family) Leang Burung - 1

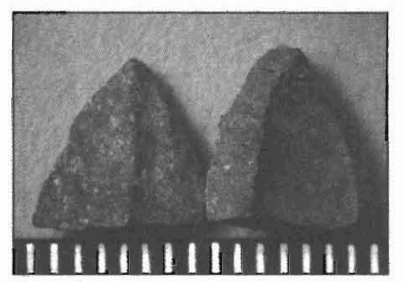

Canarium spp.

Niah

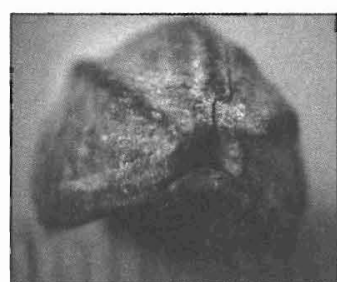

prob. Beilschimiedia sp. Leang Burung -1

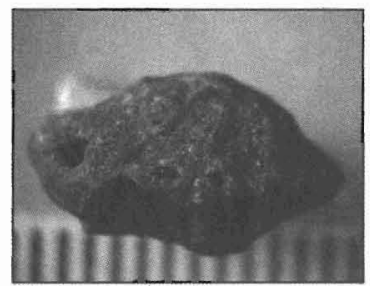

Dracontomelon dao Madai

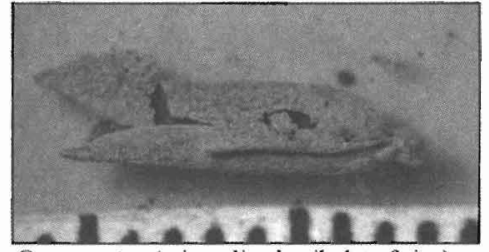

Oryza sativa (mineralized spikelet of rice) Ulu Leang

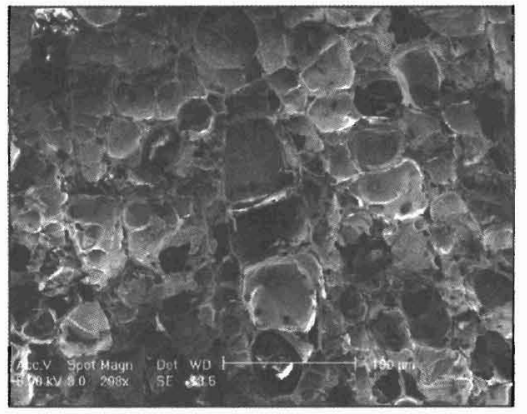

Dioscorea hispida (wild y am)

Madai

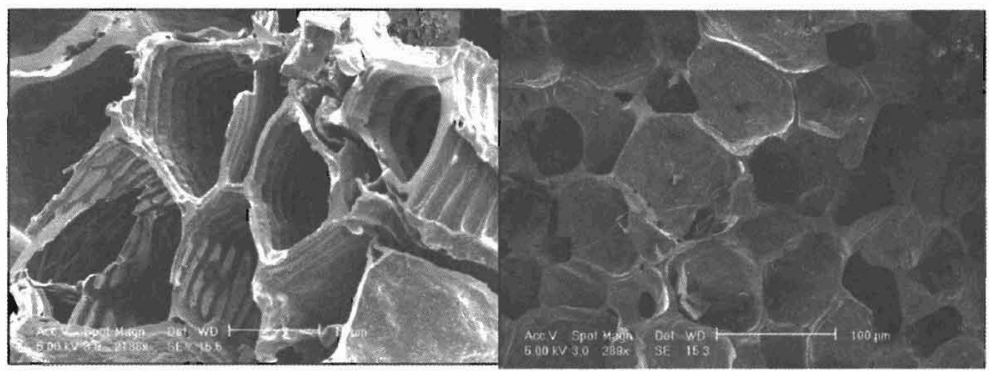

Dioscorea alata (yam)

Madai

Fig. 1. Sample images of determined plant remains from cave and rock shelter sites in Island Southeast Asia. All macro scales are in centimeters; the parenchyma scales are in micron. 
corroborate the direct evidence of the starch grains (this volume: Barton) and the indirect evidence of the bone tools (this volume: Rabett) for a long history of forest plant foraging. In the site of Madai-1 in southern Sabah, a high confidence determination of charred remains from Dioscorea alata L. (yam) and probable Colocasia sp. (taro genus) tubers was obtained, together with various remains of other plants exploited, most likely from the nearby forested areas (Paz 2001a:241). At Leang Burung, the charred remains of the tuber of probable Colocasia esculenta (taro) were recovered, again with a suite of plant remains associated with the nearby forest vegetation type (Paz 2001a:258).

Another significant way in which cave and rock shelter archaeological deposits contribute to our knowledge of the Island Southeast Asian cultural past is by establishing the antiquity of the practice of cereal agriculture in the general landscape. This can be done best when remains of processed rice or millet are found in the matrix in the form of plant macro remains or phytoliths. The best evidence for the early practice of cereal agriculture in the region comes from the Gua Sireh cave in western Sarawak, where charred rice remains and rice inclusions in pottery were recovered in cave sediments dated to ca. 2300 B.c. Diagnostic phytoliths of rice spikelets were also noted in this matrix (Beavitt et al. 1996). Convincing amounts of rice remains have been recovered from the Ulu Leang cave in Sulawesi, but there is considerable uncertainty regarding the date of these remains (more than 4000 years old, and therefore not much younger than the Gua Sireh rice) due to signs of disturbance belatedly noticed in the area where the rice remains and dating samples were collected (Glover and Higham 1996: n. 10). My own ongoing analysis of materials coming from an excavation trench farther into the interior of the cave, where the stratigraphy is deeper, revealed charred rice remains in the form of rice caryopsis (grain) and remains of rice spikelets (Fig. 1). An approximate (though potentially controversial) date of 4000 B.P. can tentatively be assigned to some of these rice remains.

Most of the determined plant materials have been traditionally exploited by Southeast Asian populations on the evidence of ethnographic studies, historical records, and current usage (Burkill 1966; Conklin 1967). It therefore seems reasonable to conclude that we can make a fairly strong analogy across deep time depths that such ancient plant remains in caves and rock shelters are likely to represent food remains, construction material debris, medicine preparation, or by-products of rituals (Table 2).

The analysis of archaeobotanical materials can help increase understanding of site formation processes inside caves and rock shelters. Water flotation, the preferred archaeobotanical method for separating plant remains from matrix, gathers both the heavy and light fraction of various other materials as well as those of plants. Investigations of the nature and frequency of untransformed plant materials such as root tissues collected through flotation can suggest to the excavator that significant bioturbation has affected the sediments. The recovery of small artifact fragments may indicate what material culture was associated with a sedimentary layer in the absence of finding large pieces. Other commonly recovered materials from flot samples include sclerotia (the mychorizal resting bodies of fungi), earthworm cocoons, and insect remains. The presence and distribution of sclerotia in the heavy or light fractions of samples may imply how long such remains have been present in the matrix, while finding quantities of sclerotia may 
Table 2. Best Determination of Plant Remains from Island Southeast Asian Cave Sites Arranged by Approximate Age ${ }^{a}$

\begin{tabular}{|c|c|c|c|c|}
\hline DETERMINATION & TYPE & APPROX. AGE B.P. & SITES & PROBABLE USE/ROLE \\
\hline Phyllanthus amarus & Seeds & 100 & Mabangog & Agriculture weed \\
\hline Phyllanthus urinaria & Seeds & 100 & Mabangog & Medicinal \\
\hline Phyllanthus sp. & Seeds & 100 & Mabangog & \\
\hline Prob. Fimbristylis sp. & Seeds & 400 & Mabangog & Building material \\
\hline $\begin{array}{l}\text { Paspalum prob. } \\
\text { conjugatum }\end{array}$ & Seeds & 400 & Mabangog & Agricultural weed \\
\hline Amaranthus sp. & Seeds & 400 & Mabangog & \\
\hline Ageratum conyzoides & Seeds & 400 & Mabangog & Medicinal \\
\hline Dioscorea hispida & Tubers & 500 & Madai & Food \\
\hline Prob. Colocasia & Tubers & $1,500-2,200$ & Madai & Food \\
\hline Dioscorea alata & Tubers & $1,500-2,200$ & Madai & Food \\
\hline Dracontomelon dao & Nut & $2,200-1,500$ & Madai & $\begin{array}{l}\text { Food \& building } \\
\text { material }\end{array}$ \\
\hline Prob. Beilschimiedia sp. & Nut & 1,500 & Leang Burung 1 & $\begin{array}{l}\text { Poss. food or building } \\
\text { material }\end{array}$ \\
\hline Prob. Casia sp. & Seeds & 3,000 & Leang Burung 1 & $\begin{array}{l}\text { Food or building } \\
\text { material }\end{array}$ \\
\hline Prob. Vigna sp. & Seeds & 3,000 & Leang Burung 1 & Food \\
\hline Prob. Ipomoea sp. & Tubers & 3,500 & Leang Burung 1 & Food \\
\hline Oryza sativa & Caryopsis & 3,800 & Gua Sireh & Food \\
\hline Oryza sativa & Caryopsis & 4,000 & Ulu Leang & Food \\
\hline Fabaceae & Seeds & 5,500 & Leang Burung 1 & Poss. food \\
\hline $\begin{array}{l}\text { Prob. Colocasia } \\
\text { esculenta }\end{array}$ & Tubers & 5,500 & Leang Burung 1 & Food \\
\hline Prob. Canarium sp. & Nut & 5,500 & Leang Burung 1 & Food \\
\hline Prob. Cucurbitaceae & Seeds & 5,500 & Leang Burung 1 & Food \\
\hline Boemeria sp. & Seeds & 7,000 & Mabangog & \\
\hline Canarium spp. & Nut & 10,000 & Niah & Food \\
\hline Cf. Dioscorea hispida & Tubers & 10,000 & Niah & Food \\
\hline
\end{tabular}

${ }^{a}$ Highest confidence are the binomial determinations, followed by the prefixed genus, then the family-level determinations. Probable use is based on ethnographic references. No attempt is made to infer the possible use of determined plant remains at the genus level with very large numbers of possible species.

point to a sediment matrix that had much plant growth with the associated accumulation of significant organic content (McWeeney 1989; Paz 2001a; Trappe 1969). Fragments of earthworm cocoons that have been recovered can verify the former location of a specific area of the matrix in respect to a previous sediment surface. This is because earthworms will have deposited their cocoons in those damp parts of a matrix that were associated with the contemporary ground surface (Edwards and Bohlen 1996). Insect remains, on the other hand, may provide a glimpse of cave ecology at specific time periods, or of the degree of bioturbation in the site caused by burrowing insects.

\section{THE BIOARCHAEOLOGY AND ARCHAEOLOGY OF ISLAND SOUTHEAST ASIA}

Examination of the comprehensive but still small collection of analyzed materials presented above indicates what archaeobotanical analysis of materials from cave 
and rock shelter sites can contribute. People-plant relationships can easily be established because most exploited plants do not grow in caves or rock shelters. As a result, the probability that plant remains ended up in the archaeological record by nonhuman means may sometimes be eliminated as an explanation for their presence, prompting a more effective focus upon explanatory models concerning how and why people in the past used these plants.

Establishing time-depth relationships for suites of plant and other biological remains has allowed the archaeobotanical data set to contribute to several major questions associated with the archaeology of Island Southeast Asia. These include environmental transformation, Austronesian cultural dispersal from mainland Southeast Asia, contacts with South America, and the nature of subsistence strategies. The analysis of pollen, phytolith, and wood charcoal frequency diagrams through cave and rock shelter deposits can easily show (at the minimum) any change in the nature of vegetation and hence environmental changes immediately outside the cave. The distribution of sclerotia and earthworm cocoons may point to changes in the environment of the cave or rock shelter itself.

The dominant Austronesian hypothesis of past human movements, articulated best by Bellwood (1997), can be tested further with archaeobotanical evidence. Paz (1999) suggested that one archaeobotanical indicator that may be used at a known time-depth is the presence of remains of yam (Dioscorea alata). The premise is that yams reached Wallacea only through human agents and that the origin of the cultivar is in mainland Southeast Asia, including what is now southern China. The oldest high confidence determination we have so far dates to $1500-2200$ cal. B.P. at Madai. If continued examinations of archaeobotanical samples fail to identify yam remains in deposits older than 4000 years, then this dominant hypothesis for the time depth of human movement associated with Austronesian cultures may be supported. Equally, reliable determinations of yam remains older than the timetable accepted for the Austronesian dispersal from Taiwan would open the discussion to other explanatory scenarios (e.g., Latinis 2000).

Another significant tuberous plant, the sweet potato Ipomoea batatas, is a good indicator for the antiquity of contact between South America (its origin) and Island Southeast Asia. It is now accepted that there was pre-Columbian contact in the Pacific. It remains to be proven that this was also the case for Island Southeast Asia.

There is also now clear potential for studying a series of caves and rock shelters across a landscape and analyzing their bioarchaeological remains in order to reconstruct the interaction of humans with environments adjacent to or surrounding the caves (see this volume: Barker et al.). The sum total of all the archaeobotanical remains determined at these sites, based on our initial suite of plant remains, is likely to establish a trend toward understanding a subsistence strategy that was centered on the exploitation of forest resources. Such an outcome may prove in the future to be as significant a system for subsistence and scale as early cereal- or rootcrop-based agricultures in the bigger region of Southeast Asia. Independent studies of phytoliths (Kealhofer 2003), starch (this volume: Barton), plant macro remains (Paz 2001a), and ethnoarchaeology (Latinis 2000) have discerned trends in the evidence indicative of a rich subsistence strategy that might properly be described as arboriculture. 
This chapter has discussed the archaeobotanical data currently available for caves and rock shelters in Island Southeast Asia, and the future potential of such studies. Given an increased emphasis on the collection of archaeobotanical material in the region and the advances in methodologies that are under way in the study of botanical remains from tropical archaeology, it is clear that these data have the potential to provide critical insights into mainstream research agendas.

\section{REFERENCES CITED}

\section{Bacus, Elizabeth}

1997 The Unto site: Excavations of a late first millennium B.c. and mid-second millennium A.D. habitation site in southern Negros island, the Philippines. Asian Perspectives 36(1): 101-141.

Barker, Graeme, Huw Barton, Paul Beavitt, Simon Chapman, Michael Derrick, Chris Doherty, Lucy Farr, David Gilbertson, Chris Hunt, Wayne Jarvis, John Krigbaum, Bernard Maloney, Sue Mclaren, Paul Pettit, Bryan Pyatt, Tim Reynolds, Garry Rushworth, and MARK STEPHENS

2000 The Niah Caves Project: Preliminary report on the first (2000) season. Sarawak Museum Journal 55 (n.s. 76): 111-150.

Barker, Graeme, Dana Badang, Huw Barton, Paul Beavitt, Michael Bird, Patrick Daly, Chris Doherty, David Gilbertson, Ian Glover, Chris Hunt, Jessica Manser, Sue McLaren, Victor Paz, Brian Pyatt, Tim Reynolds, Jim Rose, Garry Rushworth, and Mark Stephens

2001 The Niah Cave Project: The second (2001) season of fieldwork. Sarawak Museum Journal 56 (n.s. 77): 37-103.

Beavitt, Paul, Edmund Kurui, and Gill Thompson

1996 Confirmation of an early date for the presence of rice in Borneo: Preliminary evidence for possible Bidayuh/Asian links. Borneo Research Bulletin $27: 29-38$.

Bell, Martin, and Michael Walker, eds.

1992 Late Quaternary Environmental Change. London: Longman.

Bellwood, Peter

1997 Prehistory of the Indo-Malaysian Archipelago. Honolulu: University of Hawai'i Press.

Bodner, C. C.

1986 On the Evolution of Agriculture in Central Bontoc. Ph.D. diss. University of Missouri, Columbia.

BOWDERY, DOREEN

1999 Phytoliths from tropical sediments: Reports from Southeast Asia and Papua New Guinea. Indo-Pacific Prehistory: The Melaka Papers 2:159-168.

Burkill, I. H.

1966 A Dictionary of the Economic Products of the Malay Peninsula. Singapore: Government Printer.

Conklin, H. C.

1967 Ifugao ethnobotany 1905-1965 (the 1911 Beyer-Merrill report in perspective), in Studies in Philippine Anthropology: 204-264, ed. M. D. Zamora. Quezon City: Almars.

Coutts, Peter

1983 An Archaeological Perspective of Panay Island, Philippines. Cebu City: University of San Carlos.

Coutts, Peter, and J. P. Wesson

1980 Models of Philippine prehistory: A review of the flaked stone industries. Philippine Quarterly of Culture and Society 8:260-285.

Dam, R.A.C., Sander van der Kaars, and Peter A. Kershaw

2001 Quaternary environmental change in the Indonesian region. Palaeogeography, Palaeoclimatology, Palaeoecology 171(3-4): 91-95.

Dizon, Eusebio Z.

1994 A decade of archaeological research in the Philippines: 1982-1992. Philippine Quarterly of Culture and Society 22:197-222. 
Doherty, Chris, Paul Beavitt, and Edmund Kurui

2000 Recent observations of rice temper in pottery from Niah and other sites in Sarawak. Bulletin of the Indo-Pacific Prehistory Association 19:147-152.

EDwards, C. A., AND P. J. Bohlen

1996 Biology and Ecology of Earthworms, 3rd ed. London: Chapman and Hall.

Evangelista, Alfredo

1969 The Philippines: Archaeology in the Philippines to 1950. Asian Perspectives 12:97-104.

FOX, ROBERT

1959 The Philippines in Pre-historic Times. A Handbook for the First National Exhibition of Filipino Pre-history and Culture. Manila: UNESCO National Commission of the Philippines.

GLover, IAN C.

1986 Archaeology in Eastern Timor, 1966-67. Terra Australis 11. Canberra: Research School of Pacific Studies, Department of Prehistory.

1979 Prehistoric plant remains from Southeast Asia: With special reference to rice, in South Asian Archaeology 1977: 5-37, ed. M. Taddei. Naples: Instituto Universitario Orientale.

Glover, Ian C., and Charles F. W. Higham

1996 New evidence for early rice cultivation in south, southeast and east Asia, in The Origins and Spread of Agriculture and Pastoralism in Eurasia: 413-441, ed. D. R. Harris. London: UCL Press.

Gorman, Chester

1971 The Hoabinhian and after: Subsistence patterns in Southeast Asia during the late Pleistocene and early recent periods. World Archaeology 2:300-320.

1977 A priori models and Thai prehistory: A reconsideration of the beginnings of agriculture in Southeast Asia, in Origins of Agriculture: $322-355$, ed. C. A. Reed. The Hague: Mouton.

Harrisson, TOM

1958 The Great Cave, Niah, Sarawak: A ship-of-the-dead cult and related rock paintings. The Archaeological Newsletter 6:199-204.

Hastorf, Christine A.

1991 Gender, space, and food in prehistory, in Engendering Archaeology: 132-159, ed. J. M. Gero and M. W. Conkey. Oxford: Blackwell Publishers.

1993 Agriculture and the Onset of Political Inequality before the Inka. Cambridge: Cambridge University Press.

HATHER, John G.

2000 Archaeological Parenchyma. London: Archetype Press.

Higham, Charles F. W., and Rachanie Thosarat

1998 Prehistoric Thailand. London: Thames and Hudson.

Jocano, F. LANDA

1975 Philippine Pre-history. Quezon City: Philippine Center for Advanced Studies.

JUNKER, LAURA L.

1999 Raiding, Trading, and Feasting: The Political Economy of Philippine Chiefdoms. Honolulu: University of Hawai'i Press.

KEALHOFER, LISA

2003 Looking into the gap: Land use and the tropical forest of Southern Thailand. Asian Perspectives $42(1): 72-95$.

LATINIS, D. KYLE

2000 The development of subsistence system models for Island Southeast Asia and Near Oceania: The nature and role of arboriculture and arboreal-based economies. World Archaeology 32:41-67.

MaLoney, Bernard K.

1985 A preliminary pollen diagram from Pea Sijajap, North Sumatra. Modern Quarternary Research in Southeast Asia 8:35-42.

1990 Grass pollen and the origins of rice agriculture in North Sumatra. Modern Quaternary Research in Southeast Asia 11:135-161. 
MCWEENEY, L.

1989 What lies lurking below the soil: Beyond the archaeobotanical view of flotation samples. North American Archaeologist 10:227-230.

Mijares, Armand

1998 Philippine archaeology in retrospect. Hukay 1:5-16.

PAZ, VICTOR J.

1999 Neolithic human movement to Island Southeast Asia: The search for archaeobotanical evidence. Bulletin of the Indo-Pacific Prehistory Association 2:151-158.

2001a Archaeobotany and Cultural Transformation: Patterns of Early Plant Utilisation in Northern Wallacea. Ph.D. diss. University of Cambridge, Cambridge.

$2001 \mathrm{~b}$ Preliminary analysis of environmental samples from the 2000 fieldwork, pp. $72-80$ in G. Barker et al., The Niah Cave Project: The second (2001) season of fieldwork. Sarawak Museum Journal 56 (n.s. 77): 37-103.

Penny, Dan

1999 Pollen grains in sands of time: Lake sediments contribute to the archaeology of Thailand. Expedition 41(3): 32-36.

RONQUILLO, WILFREDO

1985 Archaeological research in the Philippines, 1951-1983. Bulletin of the Indo-Pacific Prehistory Association 6:74-88.

Salcedo, C. G.

1998 Mummies of the north, in Kasaysayan: The Story of the Filipino People, Vol. 2: 189-193, ed. G. Casal, E. Z. Dizon, W. P. Ronquilo, and C. G. Salcedo. Manila: Asia Publishing Co.

SAUER, CARL O.

1969 Agricultural Origins and Dispersal: The Domestication of Animals and Foodstuffs. Cambridge, MA: MIT Press.

SHIRAKiHARA, K.

1983 Batan Island and Northern Luzon: Archaeology, Ethnography, and Linguistics. Kumamoto: University of Kumamoto.

Snow, B. E., R. Shutler, D. E. Nelson, J. S. Vogel, and J. R. Southon

1986 Evidence of early rice cultivation in the Philippines. Philippine Quarterly of Culture and Society 14:3-11.

SoEjono, R. P.

1984 Important prehistoric discoveries in Indonesia. Jurnal Arkeologi Malaysia 4:16-22.

1991 On the conditions and scope of the development of archaeology in Indonesia, in Prehistoric Indonesia: A Reader: 15-28, ed. P. van de Velde. Dordrecht: Foris Publications.

Spriggs, MatThew

1989 The dating of the Island Southeast Asian Neolithic: An attempt at chronometric hygiene and linguistic correlation. Antiquity 63:587-613.

ThOMPSON, GiLl B.

1994 Wood charcoal from tropical sites: A contribution to methodology and interpretation, in Tropical Archaeology: Applications and New Developments: 9-33, ed. J. G. Hather. London: Routledge.

Trappe, J. M.

1969 Studies on Cenococcum graniforme: An efficient method for isolation from Sclerotia. Canadian Journal of Botany 47:1389-1390.

van Der KaARs, Sander, and R.A.C. Dam

1997 Vegetation and climate change in West-Java, Indonesia, during the last 135,000 years. Quaternary International 37:67-71.

White, Joyce C., Daniel Penny, Lisa Kealhofer, and Bernard Maloney

2003 Vegetation changes from the late Pleistocene through the Holocene from three areas of archaeological significance in Thailand. Quaternary International 113(1):111-132.

Yen, Douglas E.

1977 Hoabinhian horticulture? The evidence and the question from Northwest Thailand, in Sunda and Sahul: Prehistoric Studies in Southeast Asia, Melanesia and Australia: 567-599, ed. J. Allen, J. Golson, and R. Jones. London: Academic Press. 


\section{ABSTRACT}

This paper presents the state of archaeobotanical research at rock shelters and cave sites in Island Southeast Asia and its potential for enhancing our knowledge of the region's prehistory. It takes stock of what has been done, what is being done, and the prospects for archaeobtanical research in the region. This paper argues that the knowledge we generate from archaeobotany, in tandem with other methodologies, can lead to a better understanding of past subsistence strategies in the region. It also takes the view that knowledge derived from analyzing cave deposits is better utilized when seen in relation to the wider human landscape, at whatever scale a study takes. KEYwords: archaeobotany, rock shelters and caves, Island Southeast Asia. 